\title{
Multi-Attribute Utility Theory for Selecting an Appropriate Procurement Method in the Construction Projects
}

\author{
*Nabil I. El Sawalhi and Osama El Agha
}

Published online: 30 August 2017

To cite this article: Nabil I. El Sawalhi and Osama El Agha. (2017). Multi-attribute utility theory for selecting an appropriate procurement method in the construction projects. Journal of Construction in Developing Countries, 22(1): 75-96. https://doi.org/10.21315/jcdc2017.22.1.5

To link to this article: https://doi.org/10.21315/jcdc2017.22.1.5

\begin{abstract}
The selection of an appropriate procurement method is becoming an increasingly important issue due to complex decision making that clients are facing early in the lifecycle of construction projects. The aim of this paper is to improve the procurement system in the construction industry by developing a model using the multi-attribute utility theory (MAUT) as a decision support system for the selection of an appropriate procurement method for construction projects in the Gaza Strip. Factors that influence the selection of an appropriate method for construction projects in the Gaza Strip are identified and the results indicate that the most significant six factors influencing the selection of procurement methods in the Gaza Strip construction projects are price competition, degree of project complexity, time constraints of the project, project size, client financial capability and client experience in procurement methods. The study concludes that there is no variety of procurement methods used in the Gaza Strip construction industry, as a traditional procurement method is preferred. This is because most professionals in the Gaza Strip are not familiar or experienced with alternative procurement methods. A model was developed using the MAUT to select the most appropriate procurement method. The MAUT as a decision support system was successful in identifying the appropriate procurement method.
\end{abstract}

Keywords: Procurement method, MAUT, Construction project

\section{INTRODUCTION}

The procurement method with respect to the construction industry can be defined as the organisational structure adopted by the client for the management of the design and construction of a building project (Masterman, 2002). Different procurement methods are used for different construction projects and thus, the correct choice may help to avoid problems and be the key to the attainment of specific project goals (Ojo and Gbadebo, 2012). Moreover, the selection of an appropriate procurement method can reduce construction project costs by an average of $5 \%$ and enhance the probability of project success (Naoum, 1994). Conversely, a wrong procurement method often leads to project failure and/or client dissatisfaction (Love, Skitmore and Earl, 1998). Thus, the selection of a procurement system becomes a very important task for clients who have the responsibility to select the most appropriate procurement method for their construction projects. This has become more imperative because the client is faced with various options to procure his project (Ojo, 2012). Many clients have been selecting procurement systems in a cursory manner and some clients even

School of Civil Engineering, The Islamic University Gaza, Gaza Strip, Gaza, PALESTINE *Corresponding author: nsawalhi@iugaza.edu.ps

(C) Penerbit Universiti Sains Malaysia, 2017. This work is licensed under the terms of the Creative Commons Attribution (CC BY) (http://creativecommons.org/licenses/by/4.0). 
use a specific procurement system by default without making a deliberate choice. A recent study in the United Kingdom found that $89 \%$ of respondents were dissatisfied with the procurement system they had previously employed (Hibberd and Djebarni, 1996). Inexperienced clients often must rely on expert advice when selecting a procurement approach, a practice that could result in inappropriate decisions with unforeseeable consequences. Experienced clients may also suffer if they simply base their selection upon biased past experiences and the conservative decisions of their in-house experts or consultants. The selection of an appropriate procurement system is one of the most important problems in the construction sector, but it is also a complex decision-making process due to risks and uncertainties. Moreover, it depends largely on the accurate identification of client requirements. At the time of the decision, however, the clients and stakeholders often have little information and the project plans are not detailed enough for the client to make a judgement about the project with a certainty of outcomes (Tran and Molenaar, 2012).

Accordingly, the decision to select the appropriate procurement method to implement a construction project is crucial. Although it does not necessarily lead to a successful project when other factors are taken into consideration, it can influence the success of the project (Ojo and Aina, 2010). The use of alternative procurement methods has increased recently due to many factors, including the increase in the complexity and the size of projects, increased owner sophistication and requirements, demand for shorter delivery periods, among others.

\section{FACTORS INFLUENCING THE SELECTION OF PROCUREMENT SYSTEM}

Several previous studies have identified a number of factors that influence the selection of a procurement system in construction. The selection criteria for project procurement influences which procurement system is most appropriate for a particular project. Because different clients have different needs and requirements, and construction projects vary considerably in every respect, no single procurement system can be suitable for every project (LUU, Thomas and Chen, 2003; Cheung et al., 2001). Moreover, there are certain criteria to establish a profile of client requirements and preferences for the procurement methods, such as speed (during design and construction), certainty, flexibility in accommodating design changes, quality, complexity, risk allocation/avoidance, responsibility, and dispute and arbitration policies (Love et al., 2005). The selection criteria identified as the most common criteria influencing the choice of a procurement method in the Malaysian construction industry are time, controllable variation, complexity, quality, price certainty, competition, responsibility division, risk avoidance, price competition, government policy and client familiarity with the procurement method (Hashim et al., 2006), whereas the results indicate that there are nine procurement selection criteria commonly used by Australian clients, namely, speed, time certainty, price certainty, complexity, flexibility, responsibility, quality, risk allocation and price competition (Thomas, LuU and Chen, 2001). No single procurement system can be applied universally on all construction projects, as each procurement system is chosen for a particular project based on certain criteria used when selecting a procurement system. Those criteria include the following: time (speed), quality, risk allocation/avoidance, flexibility to change 
design during both design and construction periods, responsibility, complexity, price competition, certainty of cost and time, disputes and arbitration, project type, client experience, availability of experienced contractor, the willingness of a client to be actively involved, project site location, client trust in other parties, political constraints, project size, regulatory impact, market competitiveness, client requirement regarding value for money, material availability and client financial capability.

The principal factors and criteria that influence the selection of a procurement system include the willingness of the client to be actively involved, flexibility to change design during both design and construction periods, risk allocation/avoidance, project size, client experience, certainty of cost and time, availability of experienced contractor, client trust in other parties, client requirement regarding value for money and project type (Onosakponome et al., $2011)$. However, the decision is not easy, as there are many factors that affect the project procurement method decision. These factors are related to time, cost, scope, quality, owner organisation, cash flow, project characteristics, risk and relationships. It is important that donors, clients and consultants understand these factors, as doing so will assist them in making the right choice regarding a procurement method for their projects (Sayegh, 2007).

When project clients, consultants and decision makers are selecting a procurement system for a project, their previous experiences play an influential role in their decisions. Accordingly, this study seeks to determine the primary criteria clients use when selecting procurement systems (Shiyamini and Rameezdeen, 2006).

With respect to the Gaza Strip construction industry, project procurement appears to be a key area in need of substantial development. From our perspective, the majority of the public and private construction projects are procured through a traditional procurement system, especially with respect to measure and pay, and given that the number of different types of procurement systems used in Gaza is less than that of other countries. The traditional system with measurement contract methods are also widely used throughout the Middle East, with the exception of Iran and Iraq. For example, Bahrain, Egypt, Jordan, the UAE, Qatar, Oman and Saudi Arabia use this method in most of their construction projects as part of the tender and contract documentation (Rosli et al., 2006). Therefore, there is a need to explore new ways to procure construction projects. Furthermore, in the Gaza Strip, the practice of procurement selection seems to be rather unstructured and ad hoc as no logical or consistent approach is used to select an appropriate procurement system for a particular project. Therefore, the development and implementation of such an approach for the selection is essential to aid clients and consultants in selecting the most appropriate procurement system. Hence, this study aims to enhance the procurement system in the Gaza Strip by supporting the clients and consultants as they seek to an appropriate procurement method for their construction projects. The main objectives of this study are as follows:

1. To study and investigate the major practices of variant types of procurement methods used in the Gaza construction industry.

2. To identify the most common factors that affect the selection of a procurement method for construction projects in the Gaza Strip. 
3. To identify and rank the most important key factors affecting the selection of a procurement method according to the clients and their perspectives.

4. To develop a framework for the selection of a procurement method in the Gaza Strip.

\section{DEFINITIONS OF PROCUREMENT METHOD}

Since this study relies primarily on investigating the key factors influencing the selection of procurement methods, it is necessary to establish the definitions of the procurement method.

Mathonsi and Thwala (2012) stated that the procurement method is a contemporary term that is known to practitioners and researchers of the construction industry by different terms. These include terms such as project approach, procurement system, procurement delivery method and project delivery system. Masterman (2002) argues that there is a need to accept that contemporary procurement methods can now embrace not only the design and construction of a project but can now also embrace the financing, operating, facilities management, etc. of a project. The following definitions best define a procurement method:

1. It is an organisational structure adopted by the client for the implementation and, at times, the eventual operation of a project (Masterman, 2002).

2. It is a comprehensive process by which designers, constructors and various consultants provide services for design and construction to deliver a complete project to the client (Molenaar et al., 2009).

3. It is a key means through which the clients create the pre-conditions for the successful achievement of project-specific objectives (Rameezdeen and Ratnasabapathy, 2006).

4. A procurement method (sometimes known as procurement system) "is an organisational system that assigns specific responsibilities and authorities to people and organisations and defines the various elements in the construction of a project" (Love et al., 1998: 222).

In conclusion, there is no specific definition of the procurement method. However, it seems more practical to say that the whole delivery system of a project is concerned when we address procurement.

\section{TYPES OF PROCUREMENT METHODS}

Davis, Love and Baccarini (2008) claim that a plethora of methods for procuring construction projects are available to meet the needs of clients. Deciding which method to use for a given project is a difficult and challenging task, as client objectives and priorities must align with the selected method to improve the likelihood of the project being procured successfully. The decision as to what procurement method should be adopted must be made as early as possible and underpinned by the business case of the client for the project. The risks and the 
potential effect on the business of the client should be considered. Davis et al. (2008) classified procurement systems into the following two major categories:

1. Traditional procurement methods (separated)

2. Non-traditional procurement methods that include the following three methods:

a. design and construct procurement method (integrated)

b. management procurement method (packaged)

c. public private partnership procurement method

Mathonsi and Thwala (2012) explain that the traditional method is called traditional because it has been in existence for such a long time and has been the only choice available for most clients of the construction industry for many years. Davis et al. (2008) stated that in the traditional approach, the employer accepts that design work is generally separate from construction. In other words, consultants are appointed for design and cost control and the contractor is responsible for performing the work. Over the past several years, the construction industry has experienced changes in a manner never observed before. The increased size and complexity of the construction projects, the financial challenges, the political and social considerations and the information technology are just some of the changes that have occurred. These changes have led to the development of alternative procurement systems other than the traditional one. Although the non-traditional procurement systems seem to be preferred by most clients of the construction industry, it must be emphasised that there is not yet a specific method used to select the most appropriate procurement method.

Natasa and Car-Pušić (2008) contend that many clients today are increasingly dissatisfied with the traditional approach and its operational characteristics and thus, they are actively seeking alternative methods of procurement, organisation and management to meet the increasingly complex demands.

Masterman (2002) defines a non-traditional procurement system as a diversified contemporary procurement system(s) that not only considers design and construction but also considers financing, operating and facility management. Furthermore, he defines the design and constructs procurement method as, "an arrangement where one contracting organisation takes sole responsibility, normally on a lump sum fixed price basis, for the bespoke design and construction of a client's project".

Mathonsi and Thwala (2012) explain that the design and construct procurement method is a system where one organisation, usually but not exclusively the contractor, takes responsibility for the design and construction of the project, at least in theory. The client deals only with one organisation. Davis et al. (2008) contends that according to the design and construct procurement method, a contractor accepts responsibility for some or all of the design. Similarly, El Wardani (2004) clarifies that in the design and construct contract, there is usually a single point of responsibility. Thus, the employer has the advantage of having to address only one firm and as a consequence, only one firm to blame if things go awry. In practice, the employer's requirements are detailed to the extent that the design contribution and liability of the contractor are diminished. 
Mathonsi and Thwala (2012) posit that under a management-oriented procurement system, the management of the project is performed by an organisation working with the designer and other consultants to produce the designs and manage the physical operations that are then executed by the contractors. Davis et al. (2008) state that several variants of the management procurement method exist, including management contracting, construction management, and design and manage. There are some subtle differences among these procurement methods. With respect to contract management, the contractor has direct contractual links with all the contractors and is responsible for all construction work. In construction management, a contractor is paid a fee to professionally manage and oversee the project, develop a programme, coordinate the design and construction activities and facilitate collaboration to improve the project's constructability.

Larmour (2011) explains that the public private partnership procurement method involves two or more organisations working together to improve performance by agreeing to mutual objectives, devising a way to resolve disputes and committing themselves to continuous improvement by measuring progress and sharing in the gains and the losses. Examples of this method include framework agreements and joint ventures. Table 1 clarifies advantages and disadvantages and suggests when each procurement method should be used.

Table 1. Advantages and Disadvantages for Each Type of Procurement Method

\begin{tabular}{|c|c|c|c|c|}
\hline No. & $\begin{array}{l}\text { Procurement } \\
\text { Method }\end{array}$ & Advantages & Disadvantages & When to Use \\
\hline 1 & $\begin{array}{l}\text { Traditional } \\
\text { procurement } \\
\text { method }\end{array}$ & $\begin{array}{l}\text { a. Accountability } \\
\text { as the result of } \\
\text { competitive } \\
\text { selection } \\
\text { b. Competitive } \\
\text { equity } \\
\text { c. Price certainty } \\
\text { at the award of } \\
\text { the contract } \\
\text { d. Variations } \\
\text { (changes) in } \\
\text { the contract } \\
\text { are relatively } \\
\text { easy to arrange } \\
\text { and manage } \\
\text { e. A tried-and-test } \\
\text { method of } \\
\text { procurement } \\
\text { with which the } \\
\text { market is } \\
\text { familiar }\end{array}$ & $\begin{array}{l}\text { a. Process to } \\
\text { produce the } \\
\text { full contract is } \\
\text { timely } \\
\text { b. Overall project } \\
\text { duration may } \\
\text { be longer than } \\
\text { other } \\
\text { procurement } \\
\text { methods } \\
\text { c. The contractor } \\
\text { has no input } \\
\text { into the design } \\
\text { or planning of } \\
\text { the project }\end{array}$ & $\begin{array}{l}\text { a. The } \\
\text { programme } \\
\text { allows sufficient } \\
\text { time } \\
\text { b. Consultant } \\
\text { design is } \\
\text { warranted } \\
\text { c. The client } \\
\text { wishes to } \\
\text { appoint } \\
\text { separate } \\
\text { designers and } \\
\text { contractors } \\
\text { d. Price certainty } \\
\text { is wanted } \\
\text { before the } \\
\text { construction } \\
\text { begins } \\
\text { e. Product quality } \\
\text { is required } \\
\text { f. The balance of } \\
\text { risk is shared } \\
\text { between the } \\
\text { client and the } \\
\text { contractor }\end{array}$ \\
\hline
\end{tabular}


Table 1. (continued)

\begin{tabular}{|c|c|c|c|c|}
\hline No. & $\begin{array}{l}\text { Procurement } \\
\text { Method }\end{array}$ & Advantages & Disadvantages & When to Use \\
\hline 2 & $\begin{array}{l}\text { Design and } \\
\text { construct } \\
\text { procurement } \\
\text { method }\end{array}$ & $\begin{array}{l}\text { a. Client } \\
\text { addresses one } \\
\text { firm, thus } \\
\text { reducing the } \\
\text { need to } \\
\text { commit } \\
\text { resources and } \\
\text { time to } \\
\text { separate } \\
\text { contracting } \\
\text { designers and } \\
\text { contractors } \\
\text { b. Price certainty } \\
\text { is obtained } \\
\text { before } \\
\text { construction } \\
\text { commences } \\
\text { c. Overlap of } \\
\text { design and } \\
\text { construction } \\
\text { activities can } \\
\text { reduce project } \\
\text { time } \\
\text { d. Improved } \\
\text { constructability } \\
\text { due to the } \\
\text { input of the } \\
\text { contractor into } \\
\text { the design }\end{array}$ & 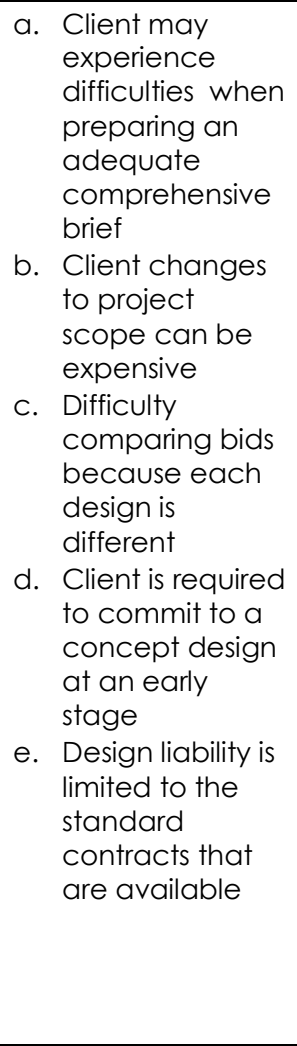 & $\begin{array}{l}\text { a. Building is } \\
\text { functional } \\
\text { rather than } \\
\text { prestigious } \\
\text { b. Building is } \\
\text { simple rather } \\
\text { than complex } \\
\text { and it does } \\
\text { not require } \\
\text { technical } \\
\text { innovation } \\
\text { c. Brief for scope } \\
\text { design is likely } \\
\text { to change } \\
\text { d. Programme } \\
\text { can be } \\
\text { accelerated } \\
\text { by } \\
\text { overlapping } \\
\text { design and } \\
\text { construction } \\
\text { activities } \\
\text { e. Single } \\
\text { organisation is } \\
\text { required to } \\
\text { take } \\
\text { responsibility } \\
\text { and risk for } \\
\text { design and } \\
\text { construction }\end{array}$ \\
\hline 3 & $\begin{array}{l}\text { Management } \\
\text { procurement } \\
\text { method }\end{array}$ & $\begin{array}{l}\text { a. The client } \\
\text { addresses only } \\
\text { one firm } \\
\text { b. Potential for } \\
\text { time savings for } \\
\text { the overall } \\
\text { project as } \\
\text { design and } \\
\text { construction } \\
\text { activities } \\
\text { overlap } \\
\text { c. Works } \\
\text { packages can } \\
\text { be let } \\
\text { competitively } \\
\text { at current } \\
\text { prices }\end{array}$ & $\begin{array}{l}\text { a. Price certainty is } \\
\text { not achieved } \\
\text { until the final } \\
\text { works package } \\
\text { has been let; } \\
\text { client must be } \\
\text { informed and } \\
\text { proactive } \\
\text { b. Poor price } \\
\text { certainty } \\
\text { c. Time and } \\
\text { information } \\
\text { control is } \\
\text { required }\end{array}$ & $\begin{array}{l}\text { a. The project is } \\
\text { large, } \\
\text { complex, fast } \\
\text { moving and } \\
\text { early } \\
\text { completion is } \\
\text { desired } \\
\text { b. The client } \\
\text { has a } \\
\text { considerable } \\
\text { degree of } \\
\text { flexibility } \\
\text { regarding } \\
\text { design } \\
\text { matters } \\
\text { c. The project } \\
\text { required } \\
\text { effective cost } \\
\text { control }\end{array}$ \\
\hline
\end{tabular}

(continued on next page) 
Table 1. (continued)

\begin{tabular}{|c|c|c|c|c|}
\hline No. & $\begin{array}{l}\text { Procurement } \\
\text { Method }\end{array}$ & Advantages & Disadvantages & When to Use \\
\hline 3 & $\begin{array}{l}\text { Management } \\
\text { procurement } \\
\text { method }\end{array}$ & $\begin{array}{l}\text { d. Improved } \\
\text { constructabil } \\
\text { ity through } \\
\text { constructor } \\
\text { input into } \\
\text { the design } \\
\text { e. Roles, risks } \\
\text { and } \\
\text { responsibiliti } \\
\text { es for all } \\
\text { parties are } \\
\text { clear } \\
\text { f. Flexibility for } \\
\text { changes in } \\
\text { design }\end{array}$ & $\begin{array}{l}\text { d. The client } \\
\text { must } \\
\text { provide a } \\
\text { good } \\
\text { quality brief } \\
\text { to the } \\
\text { design } \\
\text { team }\end{array}$ & \\
\hline
\end{tabular}

Although there are many procurement systems, most of the clients prefer to use the traditional method due to its known methodology and simple application. Some clients, however, do tend to use different procurement systems when they have a special type of project. There is no specific method to follow when attempting to identify which procurement method should be employed.

\section{Local Studies}

Enshassi and Modough (2012) claim that a project can be procured using different procurement methods ranging from single source procurement, such as direct hiring, negotiation and restrictive bid, to open competition procurement. A client may select a contractor through competitive bidding, such as the lowest-bidder system and the non-lowest-bidder system. Regardless, the procurement type is a critical decision because it defines the method to be used when selecting the key player in the project, which is the construction firm that is expected to deliver the project. Thus, this decision greatly impacts performance because if the construction firm is not qualified or is unable to achieve the project goals, serious problems may arise during and after construction.

Different procurement systems with different evaluation criteria have been developed to assist client during the contractor selection process. The main advantage of these methods and evaluation systems is that they provide a systematic and objective procurement approach that considers numerous factors other than the bid price.

The findings obtained from three case studies in the Gaza Strip indicate the existence of a proportional relation between awarding bids to the lowest bidder and the problems encountered during implementation when using a traditional procurement method. The three cases in this study awarded contracts to the lowest bidding contractors and the results reveal the following problems: a considerable delay in the project handover, disputes among the project partners, 
claims of the contractor against the client that led to disputes, poor quality of certain items and an increase in the final project cost.

Accordingly, there is a need to change the traditional system for the selecting of contractors and the awarding of contracts from the lowest bid selection practice to a multi-criteria selection practice. This can be implemented by establishing alternative procurement methods to select contractors based on technical and financial criteria.

The World Bank Country Procurement Assessment Report, West Bank and Gaza (World Bank, 2004) reveals that the most used procurement methods for works and goods are national competitive bidding (NCB) and shopping (Table 2).

Moreover, with respect to national shopping (NS), in many cases, (1) municipalities do not use written invitations to solicit quotes or bids, (2) local governments do not prepare quotation evaluation reports and do not issue purchase orders but rely instead on the quotes opening minutes and committee decisions and (3) the values of some contracts exceed the NS thresholds.

With respect to NCB, (1) for most projects during the period of the intifada, the time allowed to bidders to submit bids was much less than the 30 days required under the trust fund agreement and (2) with regards to the ministry of health component, more than one bid submission place address and bid opening address were listed in the bidding documents.

Ultimately, Sole Source (Direct Contracting) was used, even though the trust fund agreement did not stipulate its use and no-objections were sought. Procurement documents noted that, in many cases, key information was missing.

Table 2. West Bank Project Cost by Procurement Method

\begin{tabular}{|c|c|c|c|c|c|}
\hline \multirow[b]{2}{*}{ Type } & \multicolumn{4}{|c|}{ Procurement Method } & \multirow{2}{*}{$\begin{array}{l}\text { Total Financing } \\
\text { (USD Million) }\end{array}$} \\
\hline & ICB & NCB & Other & NBF & \\
\hline \multicolumn{6}{|c|}{ USD Million } \\
\hline \multirow{2}{*}{ Works } & 12.60 & 170.24 & 50.98 & 1.17 & 234.99 \\
\hline & 0.00 & 103.31 & 41.37 & 0.00 & 144.68 \\
\hline \multirow{2}{*}{ Goods } & 9.37 & 2.67 & 5.59 & 0.16 & 17.79 \\
\hline & 4.37 & 1.57 & 6.96 & 0.00 & 12.90 \\
\hline \multirow{2}{*}{ Services } & 11.52 & 0.60 & 9.49 & 2.53 & 24.14 \\
\hline & 10.52 & 0.60 & 8.50 & 0.00 & 19.62 \\
\hline \multirow{2}{*}{ Miscellaneous } & 0.00 & 2.63 & 29.34 & 9.89 & 41.86 \\
\hline & 0.00 & 2.63 & 27.85 & 0.00 & 30.48 \\
\hline \multirow{2}{*}{ Total } & 33.49 & 176.14 & 95.40 & 13.75 & 318.78 \\
\hline & 14.89 & 108.11 & 84.68 & 0.00 & 207.68 \\
\hline
\end{tabular}

Note: $I C B$ = international competitive bidding; $N B F=$ national bidding finance

Source: World Bank (2004) 


\section{DEVELOPING A FRAMEWORK}

The selection of the most appropriate procurement method to implement a construction project is crucial. Although it does not necessarily lead to a successful project, when other factors are taken into consideration, the procurement method can influence the success of the project. That said, it is observed that clients and consultants in the Gaza Strip do not have a specific procedure for selecting the best procurement method to implement their construction projects, but rather, they base their decision on familiarity with a particular method. Hence, clients use procurement methods compatible with their corporate environments, which mean that most clients in the Gaza Strip use the traditional procurement method because they lack the relevant experiences and are unfamiliar with other nontraditional methods. This lack of awareness of alternative methods is largely because there is no theoretical framework from which to derive either an ideal or optimum approach to select the most appropriate procurement method.

Hence, one of the objectives of this study is to develop a framework using the multi-attribute utility theory (MAUT) as a decision support system for the selection of an appropriate procurement method for construction projects in the Gaza Strip. The conceptual framework of the MAUT matches the prioritised factors of the client with the benchmarked performance of the procurement methods, thus identifying the selection criterion (utility coefficient) to be used to select the appropriate procurement methods for the various construction projects in the Gaza Strip.

\section{MAUT Approach}

Fellows et al. (1983) states that a MAUT is a methodology that can be used as a tool to measure objectivity in an otherwise subjective area of management. As a procurement system is the overall managerial approach by which a client commissions and obtains a project, the MAUT is considered the foremost technique appropriate for examining the criteria of clients, the preferences of procurement experts and the weights of consultants for each method in the most objective way. By indicating the relative utility of each client requirement and the procurement method against a numerical scale, it is possible to obtain a set of utility factors.

The MAUT is used primarily to solve complex problems that involve the consideration of several criteria in relation to different outcomes. The decision makers assess the values of the possible outcomes based on utility, i.e., the relative desirability of each possible outcome.

Ojo and Aina (2010) illustrate that the MAUT involves these four steps:

1. The client weights the relative importance of each significant factor that affects the selection of the procurement method.

2. Rationalised priority ratings are calculated by dividing each of the priority ratings by the sum of all the ratings and are then entered into the decision chart. The sum of the rationalised priority ratings should always be equal to 1.

3. Each rationalised priority rating is taken in turn and multiplied by each of the utility factors and the results are then entered into the appropriate columns. 
4. The totals of each of the result columns under each procurement method are calculated and ranked in descending order. The most appropriate procurement method is the method with the highest total.

\section{DATA COLLECTION PROCEDURE}

A survey questionnaire is designed to obtain further information to support the study objectives and it is based on the identified main and sub-factors that affect the selection of the best procurement method for construction projects in the Gaza Strip. Furthermore, it is intended to assist in the formulation of a model for the selection of procurement methods. After the preliminary testing of the questionnaire, a pilot study was conducted to evaluate the questionnaire. The validity and reliability tests were conducted according to the pilot study. Procurement specialists and engineers from consulting offices were involved in the decision of selecting a procurement method because of their experiences in procurement management for large construction projects in the Gaza Strip. The selected experts were asked to prioritise the factors that influence the selection of a procurement method based on a Likert scale. According to the results of the sample sizes, 68 organisations, i.e., 29 procurement experts and 39 consultants from consulting offices of engineers of the first class, responded to the survey. The data were then analysed using the Statistical Package for Social Sciences (SPSS) and the factors were ranked according to the relative importance index (RII). The factors with an importance index equal to or above $81 \%$ were recognised as important significant factors to be used in the factor analysis based on the consensus of the respondents.

Based on the analysis of the questionnaire results, 10 factors were identified as significant important factors affecting the selection of the procurement method for construction projects in the Gaza Strip. These factors include price competition ( $R \|=89.80 \%)$, degree of project complexity (RII = $88.60 \%$ ), time constraints of the project (RII $=87 \%)$, project size (RII $=86.20 \%$ ), client financial capability ( $R \|=85.80 \%)$, client experience in procurement methods (RII = 85\%), availability of qualified personnel (procurement expert) (RII $=84.80 \%$ ), risk avoidance/allocation ( $R \|=83.20 \%$ ), project type and nature (RII $=82 \%$ ) and availability of procurement system in the local market (RII $=81.40 \%$ ). The most common procurement method selected by the respondents from construction projects in the Gaza Strip was a traditional procurement method, i.e., separated method, which represents approximately two-thirds (69.10\%) of the total sample. This high percentage is a negative indicator in that its intimates that there is no variety of procurement methods selected and used in construction projects in the Gaza Strip.

Furthermore, the results reveal that $75 \%$ of the respondents are familiar with the traditional procurement method and that this method is widely used, known and spread throughout different organisations in the Gaza Strip, whereas only $25 \%$ of the respondents are familiar with other procurement methods. 


\section{Data Analysis}

Considering a decision-making problem with $M$ alternative procurement methods and $N$ significant factors whereby the alternative procurement methods are denoted as ai (for $i=1,2,3, M$ ) for significant factors and as $C j$ (for $j=1,2,3, N$ ). The decision maker knows the performance values of aij (for $i=1,2,3, M$; and $j=1$, $2,3, N$ ) of each procurement method in terms of each of the significant decision factors. Furthermore, for each significant decision factor, the decision maker has determined its relative importance and it is denoted as Cj. Finally, the relative importance of the $\mathrm{N}$ factors satisfies the following normalisation constraint:

$$
\sum_{J=1}^{n} C_{j}=1
$$

This is termed the rationalised priority rating and is calculated as:

$$
C_{j}=R I p / \sum_{P=1}^{K}(R I p)
$$

where RIp is the RII, which is used to calculate the performance of the alternatives procurement methods by an additive utility, i.e., the weighted sum model, of the following form:

$$
P i=\sum_{J=1}^{n} a i j C j
$$

For $i=1,2,3, M, P i$ is the preference value of procurement method, aij $(i=1,2,3$, M) when all the significant important factors are considered simultaneously. For the maximisation case in this study, the best alternative is the one that has the largest preference value. Table 3 presents the rationalised priority rating (Cj) of the respondents.

In an additional study, respondents, i.e., procurement specialists and engineers from consulting offices, were asked to rate the suitability of procurement methods to achieve a selection factor based on main factor groups using a Likert scale that ranged from 1 to 10. A rating of 1 indicates extremely low suitability to achieve a selection factor and a 10 indicates extremely high suitability to achieve a selection factor. The procurement methods considered were those being applied in the Gaza Strip, such as the traditional procurement method, design and build procurement method, management procurement method and public private partnership procurement method (BOT method). The benchmark performance values (aij) of these procurement methods are then calculated and the totals of each of the results columns for each procurement method are calculated and ranked in descending order. The most appropriate procurement method is the method exhibiting the highest total. 
Table 3. Rationalised Priority Rating by Respondents (Cj)

\begin{tabular}{llcc}
\hline \multirow{2}{*}{ No. } & Factor & \multicolumn{2}{c}{ Respondents } \\
\cline { 3 - 4 } & & RII (\%) & $\mathbf{C j}$ \\
\hline 1 & Price competition & 89.80 & 0.105 \\
2 & Degree of project complexity & 88.60 & 0.104 \\
3 & Time constrains of project & 87.00 & 0.102 \\
4 & Project size & 86.20 & 0.101 \\
5 & Client's financial capability & 85.80 & 0.101 \\
6 & Client's experience in procurement & 85.00 & 0.100 \\
7 & methods & & 0.099 \\
8 & Availability of qualified personnel & 84.80 & 0.097 \\
9 & (procurement staff) & 83.20 & 0.096 \\
10 & Pisk avoidance/allocation & 82.00 & 0.095 \\
\hline & Availability of procurement system & 81.40 & 1 \\
\hline
\end{tabular}

\section{MAUT Application}

Two forms were used to apply the MAUT. In the first form, procurement experts are asked to rate the suitability of the procurement methods to achieve each significant factor based on a Likert scale. The second form was developed based on the feedback of consultants to calculate the benchmark performance values (aij) of different procurement methods to identify the most appropriate procurement method for the construction project.

\section{MAUT Verification}

The verification and validation of the MAUT are essential parts of the conceptual framework development process if the MAUT is to be accepted and implemented as a decision support system, as validation ensures that the theory meets its intended requirements in terms of the methods employed and the results obtained.

\section{Verification Cases}

Two cases were considered to evaluate the MAUT verifications and to measure the accuracy and strength of the MAUT in selecting the most appropriate procurement method. Three procurement experts participated in the Coastal Municipalities' Water Utility project for Case 1 and three consultants participated in The Islamic University Gaza project for Case 2.

\section{Case 1: Design and build of Wadi Gaza wastewater treatment plant}

The following case presents the results of the verification of the MAUT. Three procurement experts participated in the Coastal Municipalities' Water Utility project. The design and build procurement method was selected for this project. 
The contract value for this project was USD1,304,000.00 with a project duration of 365 calendar days. The project was completed in 2013. The three experts were asked to rate the suitability of the procurement methods to achieve each significant factor using a Likert scale. The results are presented in Table 4. Table 5 displays the weighted sum model results for the selection of the most appropriate procurement method.

From the results presented in Tables 4 and 5, the weighted sum model results based on procurement experts revealed that the design and build procurement method was the most appropriate procurement method with a preference value of $\mathrm{Pi}=8.34$. The management procurement method was ranked as the second most appropriate procurement method, with a preference value of $\mathrm{Pi}=7.88$. This means that if a client has a construction manager, he (the client) can consider the management procurement method. The traditional system was ranked as the third most appropriate procurement method for this project, with a preference value of $\mathrm{Pi}=7.76$ and the public private partnership procurement method was ranked as the least appropriate procurement method, with a preference value of $\mathrm{Pi}=7.25$.

The procurement manager of this project was later been asked about the performance of the project with respect to procurement issues. The procurement manager confirmed that this method was the most appropriate option for the project, thus verifying the MAUT approach.

\section{Case 2: Construction of continuous medical education centre at The Islamic University Gaza}

The second case that was used to verify the MAUT was to construct a continuous medical education centre at The Islamic University Gaza. This project was completed in 2010 and constructed under the supervision of the engineering office. The MAUT verification was conducted by selecting three external consultants for this project. The traditional procurement method combined with the measure and pay method was selected for this project. The contract value of this project was USD309,000.00 and the project duration was 120 calendar days. The three external consultants were asked to rate the suitability of the procurement methods to achieve each significant factor based on a Likert scale. The results, presented in Tables 6 and 7, reveal the weighted sum model results for the selection of the appropriate procurement method.

From the data presented in Tables 6 and 7, it was concluded that the weighted sum model results obtained from consultants revealed that the traditional procurement method was the most appropriate procurement method option to implement in this project with a preference value of $\mathrm{Pi}=7.88$. The management procurement method was ranked the second most appropriate procurement method with a preference value of $\mathrm{Pi}=7.73$ and the design and build method was ranked the third most appropriate procurement method for this project with a preference value of $P i=7.41$. Again, the public private partnership procurement method was ranked the least appropriate procurement method with a preference value of $\mathrm{Pi}=7.34$, thus verifying the MAUT theory. 


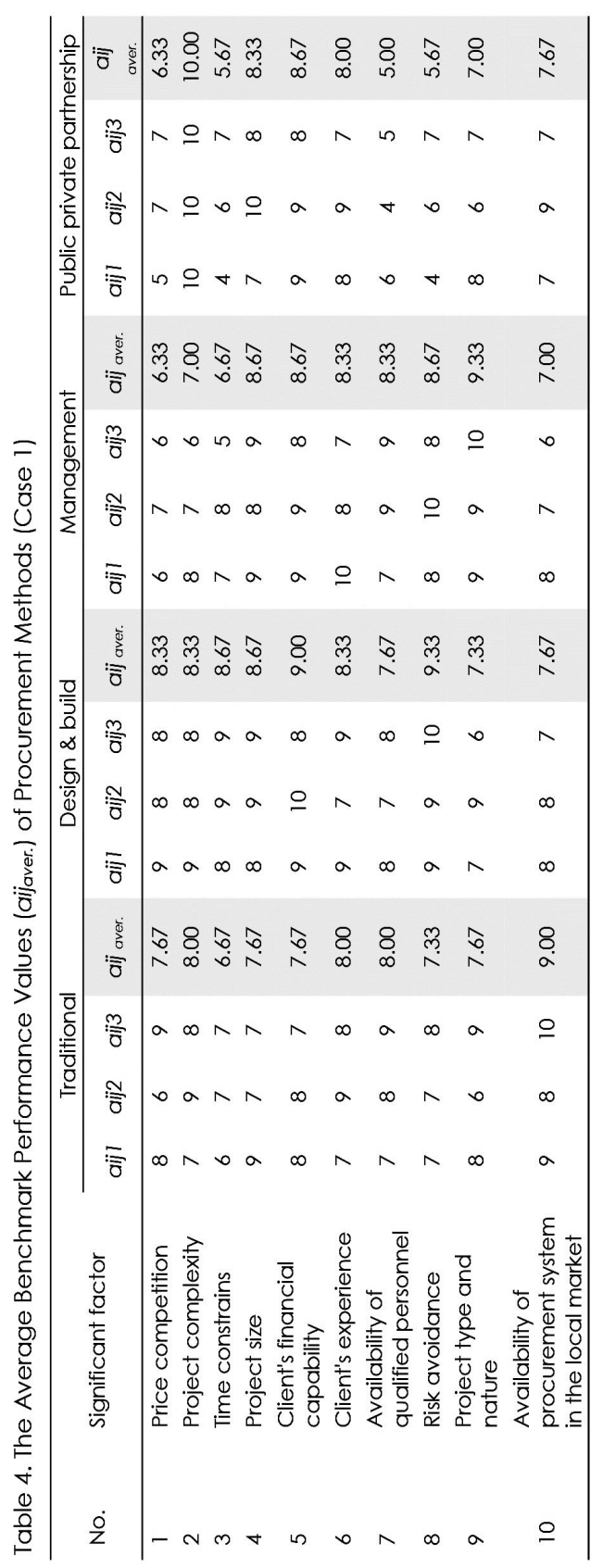

PENERBIT UNIVERSITI SAINS MALAYSIA/89 


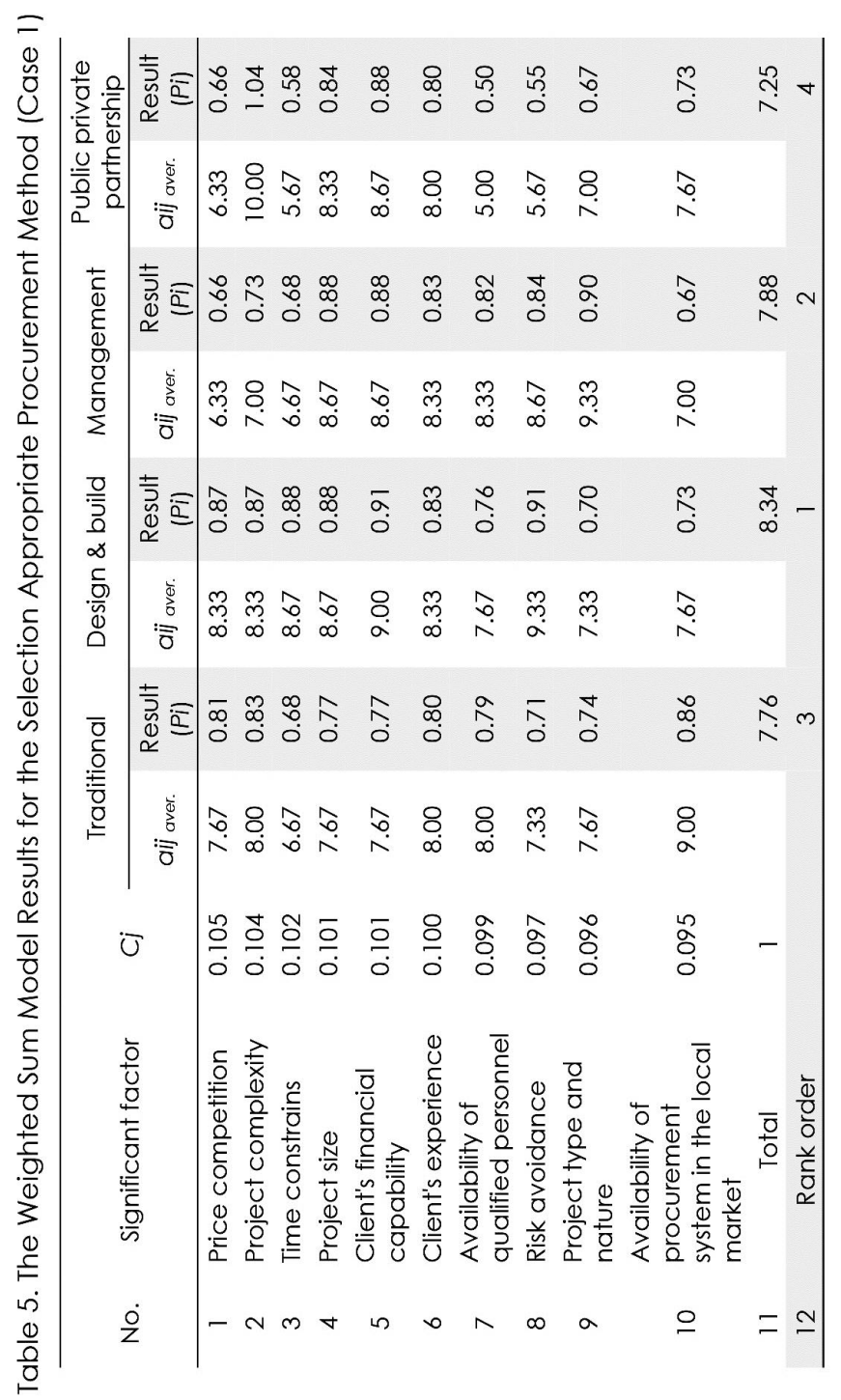

90/PENERBIT UNIVERSITI SAINS MALAYSIA 


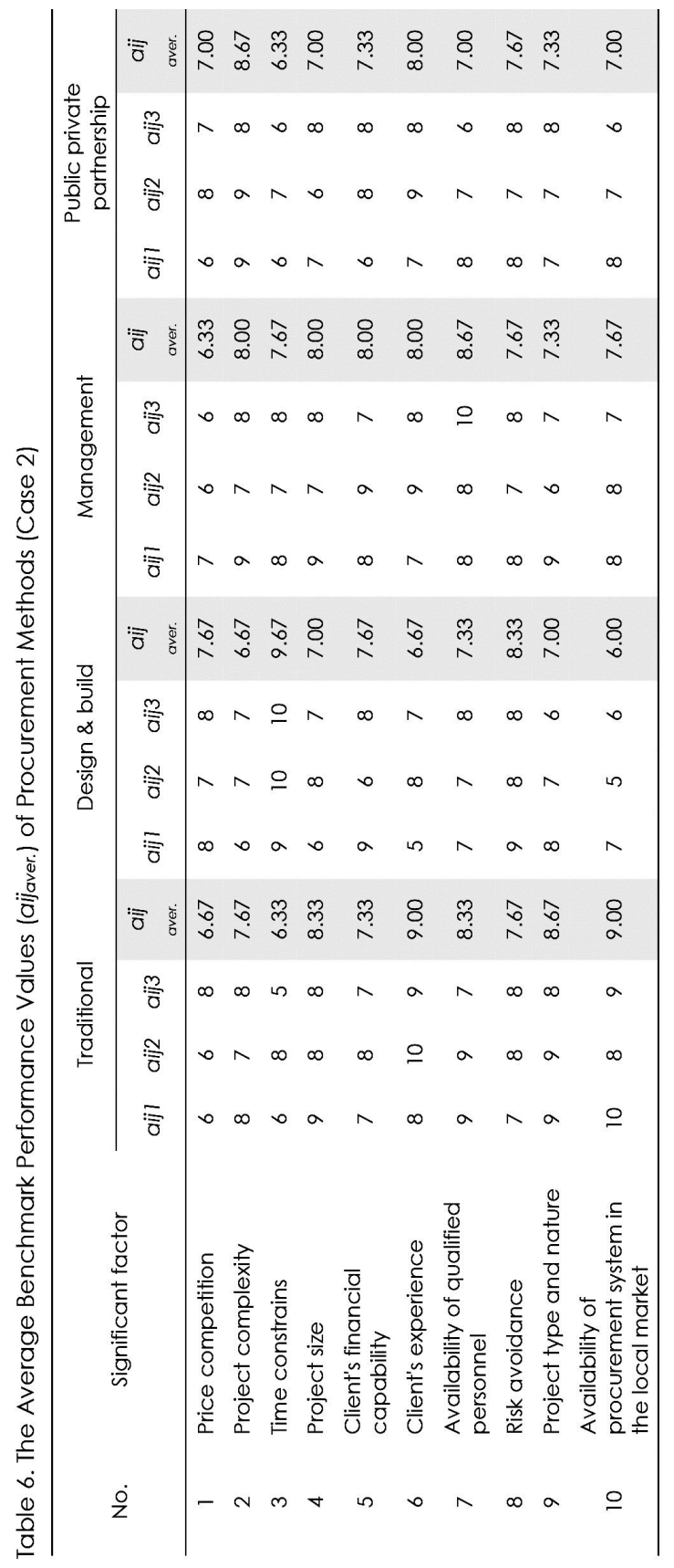

PENERBIT UNIVERSITI SAINS MALAYSIA/91 


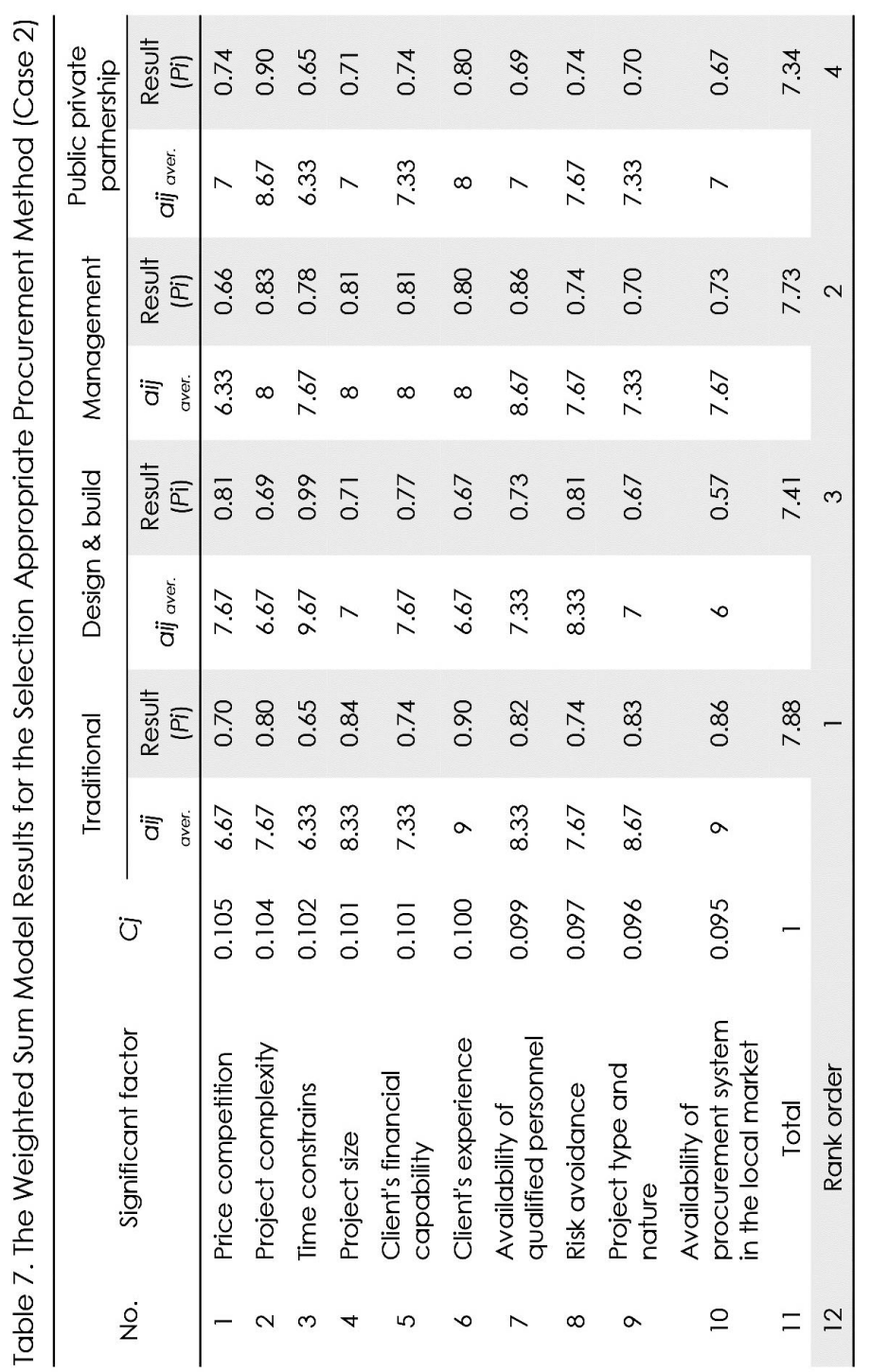

92/PENERBIT UNIVERSITI SAINS MALAYSIA 


\section{A FRAMEWORK DEVELOPMENT}

The main objective when designing the conceptual framework is to assist a decision maker in the procurement method selection. The framework facilitates the following:

1. Assists clients and their representatives in the initial decision when making an appropriate procurement selection for their construction project.

2. Ensures a systematic and consistent approach in the procurement selection through the application of relevant research methods.

3. Provides a better understanding of the selection criteria that affect the procurement selection and various types of alternative construction procurement systems in practice.

4. Provides a report on a ranked list of procurement systems.

A framework was designed for construction clients and/or their consultants, particularly for those who use an unrealistic method to select the appropriate procurement system and are responsible for the selection process. This framework guides the selection of the most appropriate procurement system for a particular type of construction project by not only considering the requirements of clients and the profile of the project but also the impact of the external environment on procurement selection. In this way, it is possible to ensure that the project is procured in an efficient and effective way that adds value for the client. The development of the model consists of three main phases, namely: (1) the database input phase, (2) the process and modelling the factors phase and (3) the data base output phase. Figure 1 presents a conceptual framework for the selection of an appropriate procurement method.

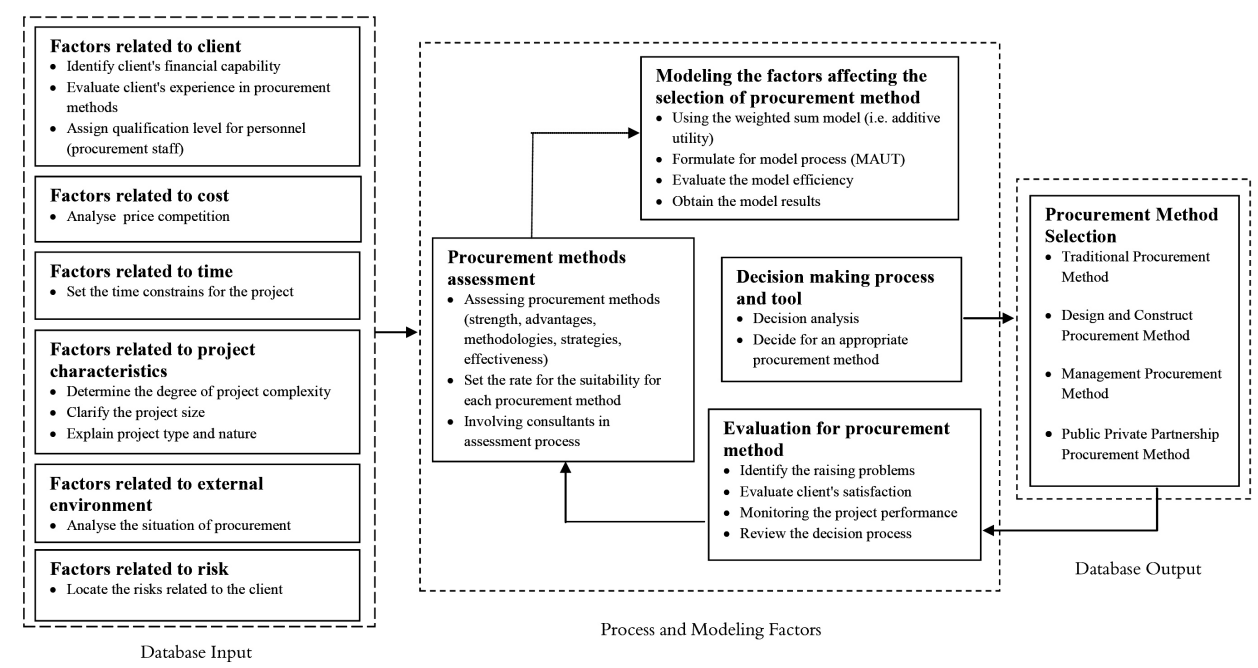

Figure 1: Framework for the Selection of an Appropriate Procurement Method 


\section{CONCLUSIONS}

There are 12 influential factors/criteria affecting the selection of procurement methods in construction projects in the Gaza Strip. It was concluded that both procurement specialists and consultants from the offices of engineers generally agree on the importance of factors affecting the selection of a procurement method. Both the conventional (traditional) and non-conventional procurement methods are currently embraced in the Gaza Strip and approximately two-thirds of the construction projects are executed using variants of the traditional procurement method, whereas other procurement methods are used infrequently. The Gaza Strip construction sector continues to exclusively use traditional methods. This presumably due to procurement staff and consultants who are well familiar with the traditional methods, a familiarity that is based on the longevity of the traditional procurement systems in the Gaza Strip construction industry.

It seems that the current procurement methods (traditional) have directly contributed to projects exceeding their estimates and bids in terms of cost and time, suggesting that this method is unsuitable for a modern, progressive construction industry in Gaza.

Among the variant types of traditional procurement methods, a measurement method based on the bill of quantities has exhibited the highest selection share. The popularity of this method is mainly due to the governmental influence on the construction industry in the Gaza Strip.

It is concluded that the combination of a national culture and an organisational culture during construction in Gaza created an environment that did not favour the use of new procurement methods. The organisational culture of construction in Gaza was characterised by the separation of design and construction from the colonial days. The construction professionals were found to be feminine collectivists, a mixed culture that did not challenge the status quo. Thus, there was no room to experiment with new procurement methods in the Gaza Strip construction industry.

The MAUT is a decision support system that was developed to help clients select the appropriate procurement method and as such, the model demonstrated the ability to identify the appropriate procurement method.

\section{REFERENCES}

Cheung, S.O., Lam, T.I., Wan, Y.W. and Lam, K.C. (2001). Improving objectivity in procurement selection. Journal of Management in Engineering, 17(3): 132139. https://doi.org/10.1061/(ASCE)0742-597X(2001)17:3(132).

Chua, D.K.H., Kog, Y.C. and Loh, P.K. (1999). Critical success factors for different project objectives. Journal of Construction Engineering and Management, 125(3): 142-150. https://doi.org/10.1061/(ASCE)0733-9364(1999)125:3(142).

Davis, P., Love, P. and Baccarini, D. (2008). Report: Building Procurement Methods. Research Project No: 2006-034-C-02. Brisbane, Australia: Icon.Net Pty. Ltd. Available at http://www.construction-innovation.info/images/pdfs/ Research_library/ResearchLibraryC/2006-034-C/reports/Report_-_Building_ Procurement_Methods.pdf.

94/PENERBIT UNIVERSITI SAINS MALAYSIA 
El Wardani, M. (2004). Comparing procurement methods for design-build projects. PhD diss. The Pennsylvania State University.

Enshassi, A. and Modough, Z. (2012). Case studies in awarding the lowest bid price in construction projects. IUG Journal of Natural and Engineering Studies, 20(1): 113-137.

Fellows, R.F., Langford, D.A., Newcombe, R. and Urry, S. (1983). Construction Management in Practice. London: Longman Scientific and Technical.

Hashim, M., Chan, M.Y.L., Ng, C.Y., Ng, S.H., Shim, M.H. and Tay, L.Y. (2006). Factors influencing the selection of procurement systems by clients. Paper presented at International Conference on Construction Industry 2006. Padang, Indonesia, 21-25 June.

Hibberd, P. and Djebarni, R. (1996). Criteria of choice for procurement methods. COBRA 1996 Proceedings of the Annual Research Conference of the Royal Institution of Chartered Surveyors (RICS). London, 19-20 September.

Larmour, J. (2011). A study of procurement routes and their use in the commercial sector. PhD diss. University of Cambridge.

Love, P.E.D., Davis, P.R., Edwards, D.J. and Baccarini, D. (2005). Uncertainty avoidance: Public sector clients and procurement selection. International Journal of Public Sector Management, 21 (7): 753-776. https://doi.org/ $10.1108 / 09513550810904550$.

Love, P.E.D., Skitmore, R. and Earl, G. (1998). Selecting an appropriate procurement method for the construction process: An empirical study. Construction Management and Economics, 16(2): 221-233. https://doi.org/ 10.1080/014461998372501.

LuU, D.T., Thomas, S. and Chen, S.E. (2003). Parameters governing the selection of procurement system: An empirical survey. Engineering, Construction and Architectural Management, 10(3): 209-218. https://doi.org/10.1108/ 09699980310478458.

Mathonsi, M.D. and Thwala, W.D. (2012). Factors influencing the selection of procurement systems in the South African construction industry. African Journal of Business Management, 6(10): 3583-3594. https://doi.org/ $10.5897 / \mathrm{AJBM} 10.978$.

Masterman, J.W.E. (2002). An Introduction to Building Procurement Systems. 2nd Ed. London: E \& FN Spon.

Molenaar, K., Sobin, N., Gransberg, D., Tamera McCuen, T.L., Sinem Korkmaz, S. and Horman, M. (2009). Sustainable, high performance projects and project delivery methods: A state-of-practice report. White Paper for the DesignBuild Institute of America and the Charles Pankow Foundation. Washington DC: The Charles Pankow Foundation and The Design-Build Institute of America.

Natasa, T. and Car-Pušić, D. (2008). "Design and build" in comparison with the traditional procurement method and the possibility of its application in the creation constructability. Proceedings of the 8th International Conference on Organization, Technology and Management in Construction. Zagreb, Croatia: Građevinski fakultet Sveučilišta u Zagrebu.

Noaum, S.G. (1994). Critical analysis of time and cost of management and traditional contracts. Journal of Construction Engineering and Management, 120(4): 687-705. https://doi.org/10.1061/(ASCE)0733-9364 (1994) 120:4(687). 
Ojo, A.E. and Gbadebo, M.A. (2012). Critical selection criteria for appropriate procurement strategy for project delivery in Nigeria. Journal of Emerging Trends in Economics and Management Sciences (JETEMS), 3(5): 422-428.

Ojo, S.O. (2012). PROMA: A decision support system to determine appropriate procurement method. Research Journal of Applied Sciences, Engineering and Technology, 4(4): 316-321.

Ojo, S.O and Aina, O.O. (2010). Developing a decision support system for the selection of appropriate procurement method for a building project in Nigeria. Global Journal of Researches in Engineering, 10(2): 18-30.

Onosakponome, O.F., Yahya, A., Abdul Rani, N.S. and Shaikh, J.M. (2011). Cost benefit analysis of procurement systems and the performance of construction projects in East Malaysia. Information Management and Business Review, 2(5): 181-192.

Rameezdeen, R. and Ratnasabapathy, S. (2006). A multiple decisive factor model for construction procurement system selection. COBRA 2006 Proceedings of the Annual Research Conference of the Royal Institution of Chartered Surveyors (RICS). London: RICS.

Rosli, A.R., Ismail, M.T., Wan Basiron, W.A., Md. Asrul, N., Wan Nordiana, W.A. and Zainab M.Z. (2006). Proceedings: Effect of Procurement Systems on the Performance of Construction. Padang, Indonesia, 21-24 June.

Sayegh, S. (2007). Factors affecting the selection of the appropriate construction management at risk contractor. Fifth LACCEI International Latin American and Caribbean Conference for Engineering and Technology (LACCEI'2007). Tampico, México: Latin American and Caribbean Consortium of Engineering Institutions (LACCEI).

Shiyamini, R. and Rameezdeen, R. (2006). Multiple decisive factor models for construction procurement system selection. Proceedings of the COBRA 2006 Conference. London: Royal Institution of Chartered Surveyors.

Thomas, N., LUU, D.T. and Chen, S.E. (2001). Decision criteria and their subjectivity in construction procurement selection. The Australasian Journal of Construction Economics and Building, 2(1): 70-80. https://doi.org/10.5130/ AJCEB.v2il.2888.

Tran, D. and Molenaar, K. (2012). Critical risk factors in project delivery method selection for highway projects. Construction Research Congress. Reston, VA: American Society of Civil Engineers, 331-340. https://doi.org/10.1061/ 9780784412329.034.

World Bank (2004). Country Procurement Assessment Report, West Bank and Gaza. Washington DC: World Bank. https://doi.org/10.1596/13881. 